\title{
Cytogenetics of the Indian Jasmines I Morphological and Taxonomical*
}

\author{
by V.S. RAMAN**
}

Received May 7, 1955

I. Introduction: The family Oleaceae comprises of about 20 genera and over 500 species distributed in the tropical and temperate regions of the World (Bailey 1949). Engler and Prantl (1897) cite about 160 species of Jasminum in the tropical and sub-tropical regions of Asia. Africa, Australia, and America and over 40 in India. Gamble (1936) describes 20 species from Madras Presidency.

The commonly cultivated jasminums are, J. sambac Ait., J. auriculatum Vahl., J. flexile Vahl. and J. grandiflorum Linn. Bor and Raizada (1946) and Krishnaswamy and Raman (1948) have given taxonomic descriptions of some species of the genus. Nalini Nirodi (1950) recorded an abnormal jasmine in which the stamens have arisen by the transformation of petals. This paper gives a short description of four varieties and forms of $J$. sambac and also the differences in leaf and flower characteristics between the wild and cultivated forms of three species (Tables I and II).

II. Materials : The species and varieties treated in this study were collected from Madras State.

III. Observations and Discussion : (a) The seedling Jasminums: Fruit set is common in all the will species. Chances are remote for the cultivated ones to. bear fruits as the flowers even in their bud stage are plucked off. During this operation, the epipetalous stamens naturally go off with the buds. As these cultivated ones have spread through clonal propagation, all collections of a species or variety show similarity in their morphological characteristics. Selfed flowers do not set fruits, but do so when left for open pollination. Seedlings were raised from plants listed in Tables I and II and all these were true to the chromosome number of their parents. However, variation in the size and shape of leaves and leaflets was observed. (b) Types of floral abnormality in J. sambac varieties: The simple type of flower has one whorl of either elliptic or ovate corolla lobes with a single corolla tube. The first type of origin is by simple fission of the corolla lobes, increase in the number of whorls without affecting the corolla tube and the two epipetalous anthers. The corolla lobes remain single or two whorled but the anthers become petaloid Type II. In type III, two or three different flowers each with its own corolla tube

\footnotetext{
* Part of thesis approved for the degree of Master of Science of the Madras University, 1952.

** Agricultural Research Institute, Coimbatore-South India.
} 
and lobes may be telescoped one inside the other. The anthers of the lowermost flower remain normal while those of the upper ones become completely or partially petaloid. Type-IV-fasciation found in stems leads to formation of single large flower with numerous bracts, calyx teeth, anthers and stigma. The flower often assumes a flattened appearnance as in a cox-comb. It is interesting that the multiplicity of petals in the flowers has no relationship with the ploidy of the variety concerned. The following gives a schematic representation of the lines of differentiation of corolla in $J$. sambac.

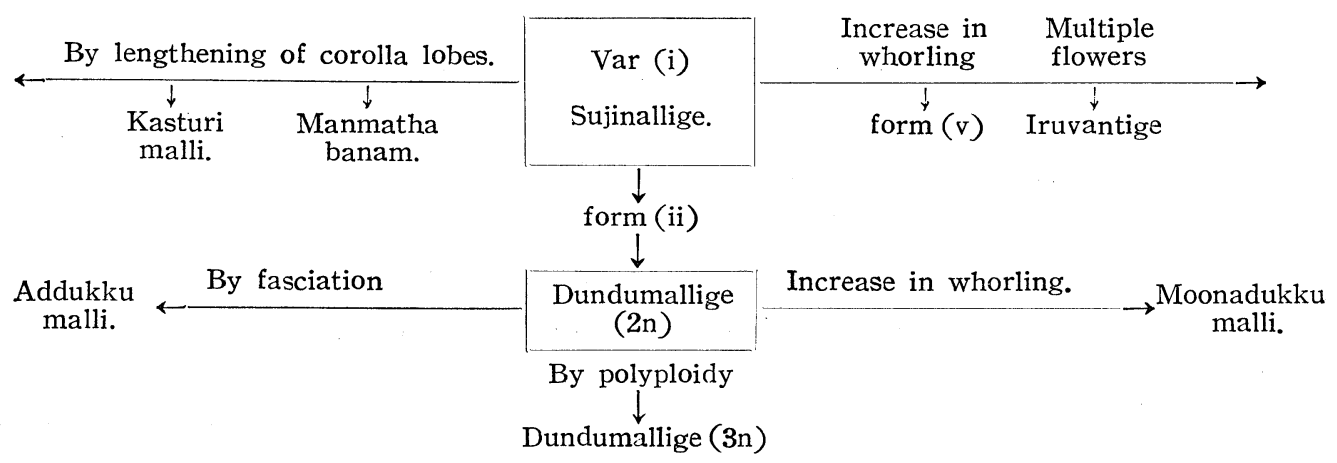

c) Considerations regarding the evolution of plants with simple, trifoliate and compound leaves. Of the different taxonomic criteria employed in the classification of the Jasminums, the character of the calyx is an important one (Appendix I). In the evolution of the Jasminums, it appears, as though coupled with the compounding of the leaves there has also been differentiation of the calyx.

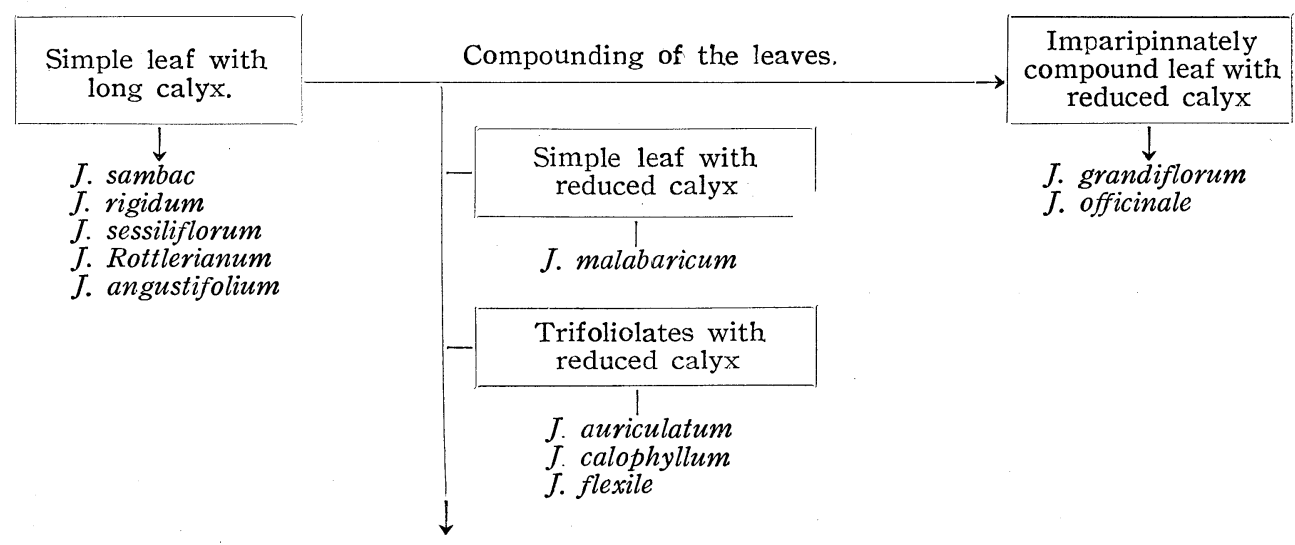

Arber (1950) cites a number of cases in which a compound ternate leaf clearly reveals its equivalence to a simple leaf. From this, it follows that in foliar development the compound leaf is derived from a simple one. In the Jasminums somewhere in the direct line of evolution from the simple to the imparipinnately compound leaf, the trifoliolates have been differentiated coupled with reduction in the length of the 
calyx through such simple leaved intermediates as exhibit a reduction in the length of the calyx ( $J$. malabaricum). Engler and Prantl (1.c) consider the simple leaf as only the transformed terminal leaf-let of the imparipinnately compound leaf, and on this basis species with imparipinnately compound leaves must be considered to be primitive and the simple leaved ones as advanced as shown below:-

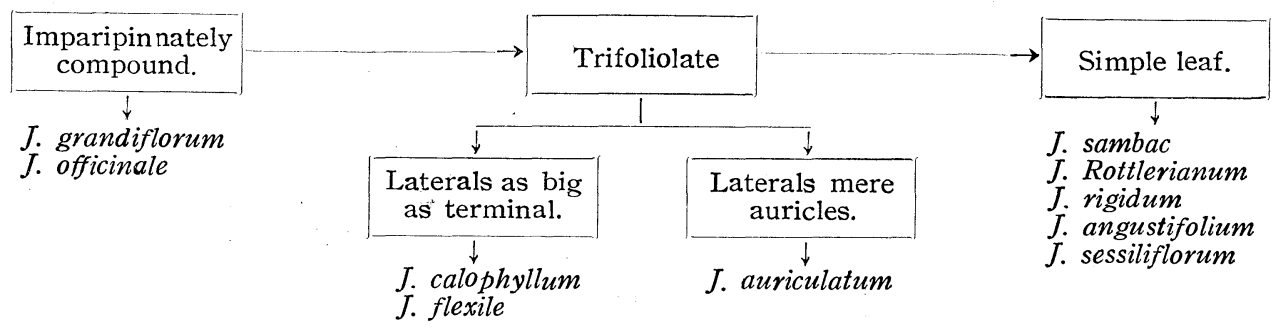

Taking the corolla lobes, the evolution may be represented as follows. In the simple leaved (wild) species the corolla lobes are linear and almost laciniate with acute tip. In the trifoliolates they are elliptic and less acute, while in the imparipinnate ones they are more ovate and obtuse. In the cultivated varieties, especially, the selection seems to have been towards the broader ones. In the varieties of J. sambac, these three grades of corolla differentiation are observed. Taking the simple leaved (wild) species with linear laciniate corolla lobes as more primitive, the scheme of evolution may be.

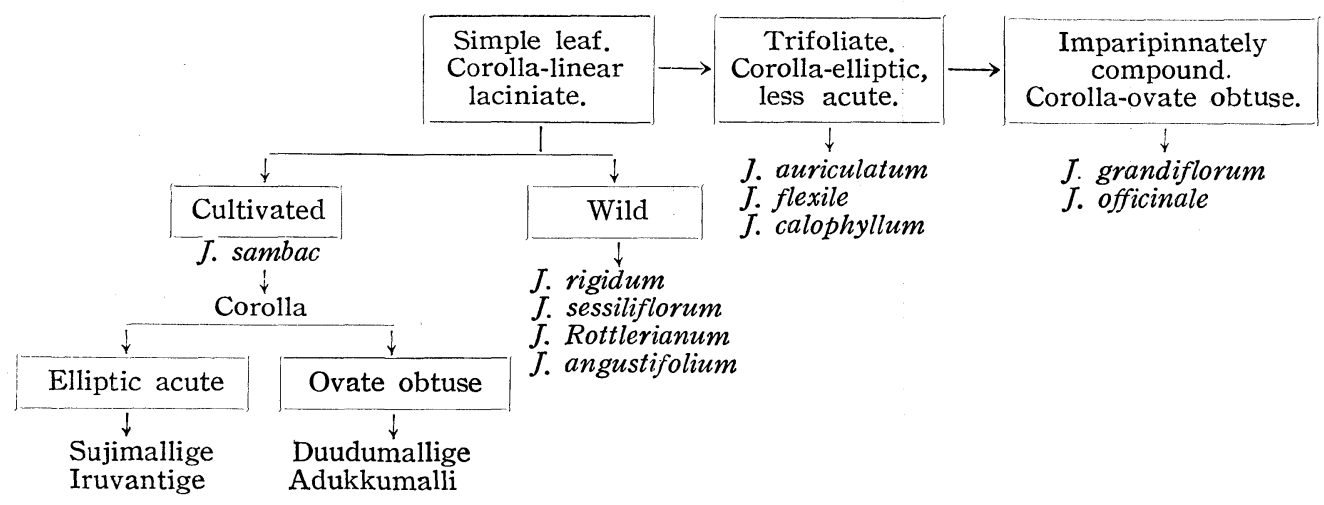

The chromosome morphology of the simple leaved species bears more resemblance to those of the trifoliolates rather than to those of the compound leaved ones. The simple leaved species are numerically greater than the trifoliates and hybridizatian between the two has not been successful.

IV. Summary: The species sambac includes two groups of plants, on with elliptic leaves and lanceolate corolla lobes, and another with ovate leaves and corolla lobes.

Differences in morphological characters were observed in plants (growing wild 
Table 1. Varieties and

\begin{tabular}{|c|c|c|c|c|}
\hline $\begin{array}{c}\text { Serial } \\
\text { Number. } \\
1\end{array}$ & $\begin{array}{c}\text { Name of } \\
\text { Species. } \\
2\end{array}$ & $\begin{array}{c}\text { Cultivated }(-) \\
\text { or Wild }(t) \\
3\end{array}$ & $\begin{array}{c}\text { Chief Characteristics } \\
4\end{array}$ & $\begin{array}{l}\text { Name of } \\
\text { Variety. } \\
5\end{array}$ \\
\hline 1 & J. sambac Ait. & - & $\begin{array}{l}\text { Group A. Leaf : simple-opp- } \\
\text { osite-elliptic-dark or yellow } \\
\text { green-Flower buds conical. } \\
\text { Lobes-elliptic to oblong-acute- } \\
\text { Single whorled-rarely two. } \\
\text { Corolla tube shorter than } \\
\text { lobes-rarely two. } \\
\\
\text { (n) } \\
\text { te-ovate or ovate elliptic- } \\
\text { gark-green. } \\
\text { globose-lobes oblong to orbi- } \\
\text { cular. }\end{array}$ & $\begin{array}{l}\text { (Kannada) } \\
\text { mallige } \\
\text { (Kar ii } \\
\text { (Kannada) } \\
\text { var iv } \\
\text { var iii } \\
\text { (Kannadige }\end{array}$ \\
\hline
\end{tabular}


forms of $J$. sambac.

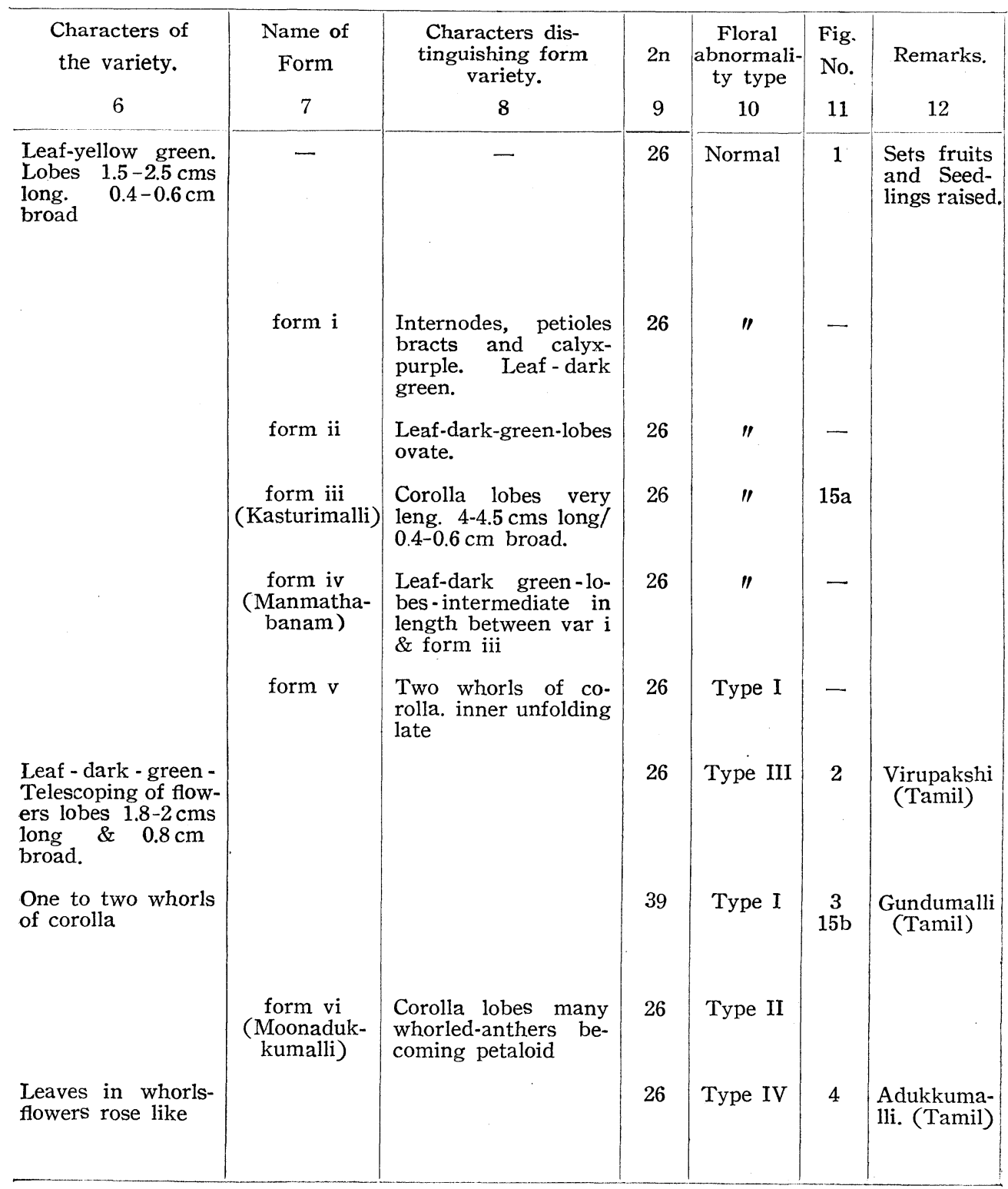




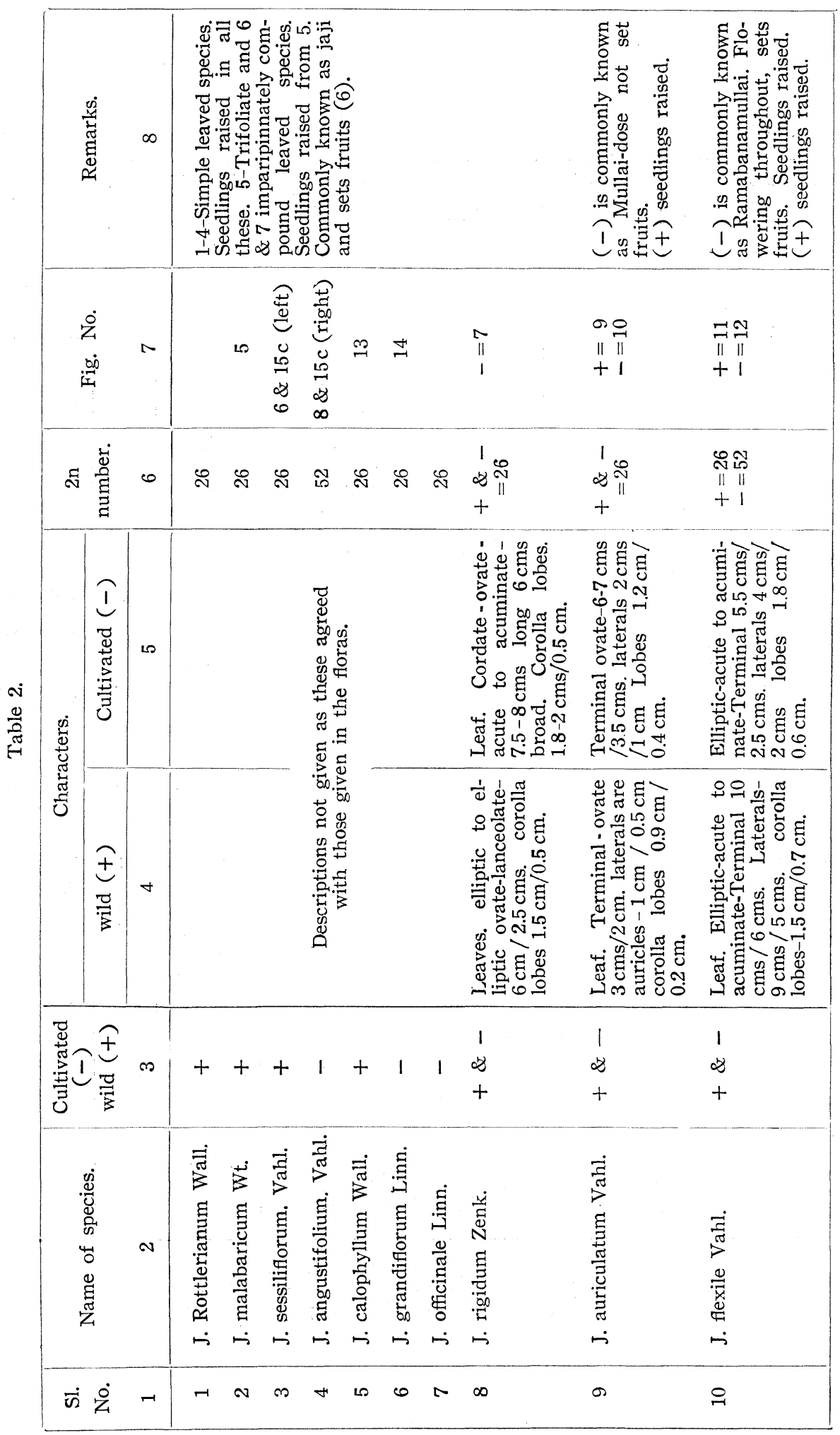



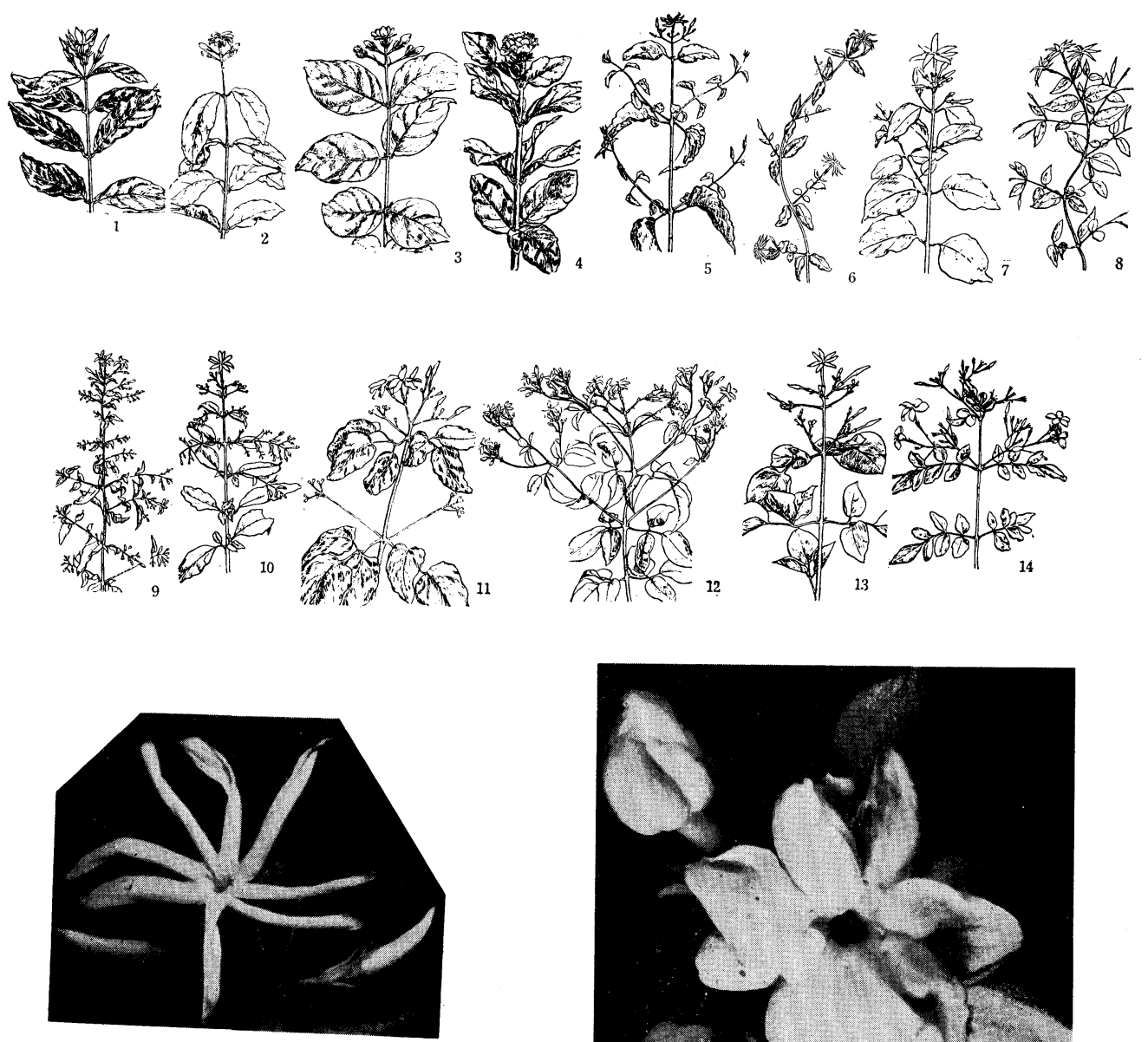

$15 \mathrm{a}$

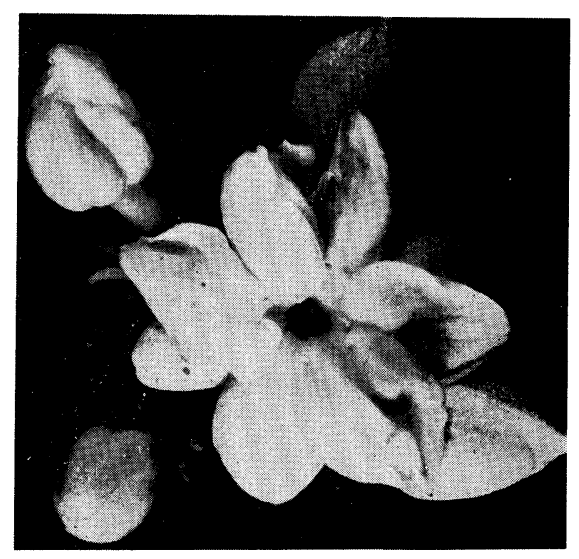

$15 \mathrm{~b}$

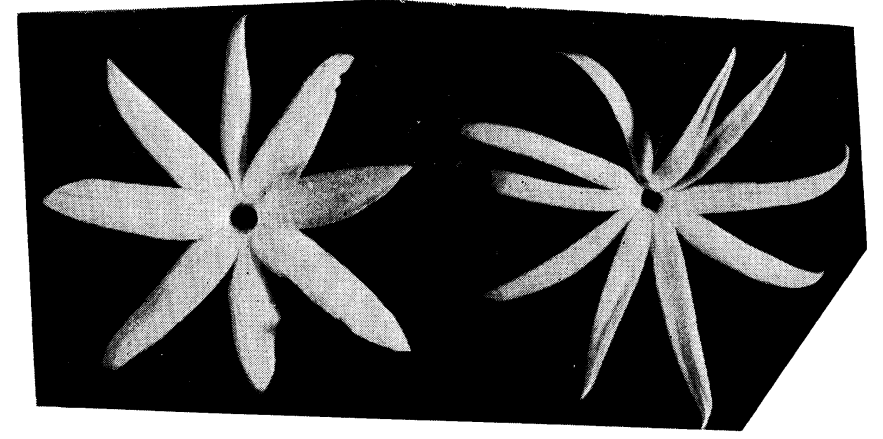

$15 c$

V.S. RAMAN: Cytogenetics of the Indian Jasmines 
and cultivated) of $J$. rigidum, $J$. auriculatum and $J$. flexile.

The seedlings of the cultivated J. flexile showed mendelian segregations for leaflet size and shape. Four types of floral abnormality in $J$. sambac varieties are described as also their probable method of origin and differentiation.

The relationship between the simple, trifoliate, and imparipinnately compound leaved species and their origin are discussed in respect of the leaves, calyx and corolla lobes.

\section{References:}

Arber, A. (1950) The Natural Philosophy of Plant from. Camb. Univ. Press.

Bailey, L. H. (1949) Manual of Cultivated Plants. McMillan \& Co., N. Y.

Bor, N. L. \& Raizada, M. B. (1946) J. Indial. Bot. Soc. 46: 2, 205.

Engler, A. \& Prantl, K. (1897) Die Naturlichen Pflanzenfamilien IV Teil. Leipzig.

Gamble, J.S. (1936) Flora of the Presidency of Madras. Part V. 785.

Krishnaswamy, N. \& Raman V.S. (1948) J. Indian. Bot. Soc. I: 7.

Nalini Nirodi (1950) Madras, agric. J. 37: 460.

\section{Appendix I}

\section{Classification of the Jasminums as given by different Systematists.}

1. Walpers C. G. (1852) Annals Botanices Systematiceae. Vol. 3.

Section I-Unifoliata

i) Calyx lobes subulate and elongate

ii) Calyx subtruncate

Section II-Trifoliata

i) Calyx shortly dentate

ii) Calyx laciniate

2. Engler and Prantl (1897).

Section I-Unifoliata

Section II-Trifoliata

Section III-Alternifolia (Leaves cut up into three or more leaflets.)

Section IV-Pinnatifolia (Leaves imparipinnately compound)

3. Hooker J. D. (1882) Flora of British India II 590 Reeve \& Co. London.

Group I. Leaves simple, calyx pubescent.

(This section proceeds from the species with long to those with short calyx teeth)

Group II. Leaves trifoliate.

Group III. Leaves imparipinnately compound.

4. Gamble (1936)

Group I. Leaves simple.

i) Calyx pubescent or glabrous

ii) Calyx snbulate or short

Group II. Leaves compound.

i) Leaves trifoliate

ii) Leaves imparipinnately compound 